\author{
INEEL/CON-04-01902 \\ PREPRINT \\ Comparison Of Tritium Component \\ Failure Rate Data
}

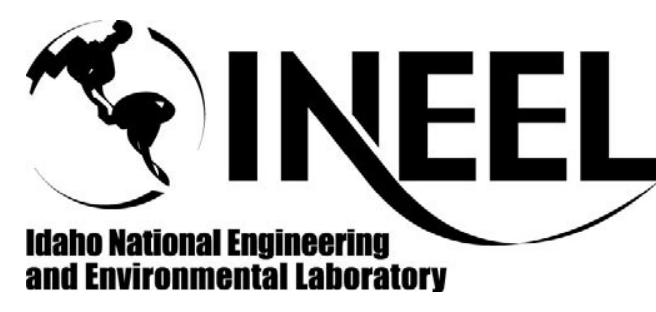

L. C. Cadwallader

September 14-16, 2004

Sixteenth Topical Meeting on the Technology of
Fusion Energy

This is a preprint of a paper intended for publication in a journal or proceedings. Since changes may be made before publication, this preprint should not be cited or reproduced without permission of the author.

This document was prepared as an account of work sponsored by an agency of the United States Government. Neither the United States Government nor any agency thereof, or any of their employees, makes any warranty, expressed or implied, or assumes any legal liability or responsibility for any third party's use, or the results of such use, of any information, apparatus, product or process disclosed in this report, or represents that its use by such third party would not infringe privately owned rights. The views expressed in this paper are not necessarily those of the U.S. Government or the sponsoring agency. 


\title{
COMPARISON OF TRITIUM COMPONENT FAILURE RATE DATA
}

\author{
L. C. Cadwallader \\ Idaho National Engineering and Environmental Laboratory, PO Box 1625, Idaho Falls, ID 83415, lcc@inel.gov
}

\begin{abstract}
Published failure rate values from the US Tritium Systems Test Assembly, the Japanese Tritium Process Laboratory, the German Tritium Laboratory Karlsruhe, and the Joint European Torus Active Gas Handling System have been compared. This comparison is on a limited set of components, but there is a good variety of data sets in the comparison. The data compared reasonably well. The most reasonable failure rate values are recommended for use on next generation tritium handling system components, such as those in the tritium plant systems for the International Thermonuclear Experimental Reactor and the tritium fuel systems of inertial fusion facilities, such as the US National Ignition Facility. These data and the comparison results are also shared with the International Energy Agency cooperative task on fusion component failure rate data.
\end{abstract}

\section{INTRODUCTION}

Tritium fuel handling for fusion facilities is an important safety issue. Inadvertent releases of tritium from the fuel cleanup, handling, and storage facility of a fusion experiment can be a dominant contributor to offsite radiological dose. Analyzing the reliability of the system equipment and the secondary confinement barriers can lead to improvements in system safety and also prove the regulatory case that the public is protected from exposure to tritium. Improved tritium confinement also protects facility workers and the environment. Existing tritium facilities operated for fusion research have considered reliability field experience data to be valuable enough to devote time and resources to collecting and analyzing the component failure information. These facilities include the Tritium Systems Test Assembly (TSTA) in the US, the Joint European Torus (JET) Joint Undertaking in the United Kingdom, the Tritium Process Laboratory (TPL) in Japan, and the Tritium Laboratory Karlsruhe (TLK) in Germany. The safe operation of these facilities, and the quantitative fault modeling of near-term designs that has been made possible by data collection activities, serve to demonstrate that fusion tritium handling systems and facilities are a mature technology that should not contribute significantly to the accident risk of a fusion experiment. Some safety personnel have suggested that this effort to collect and analyze tritium component data may be misplaced since tritium facilities for other purposes have already been licensed and operated. Most notably, military and commercial fission power reactor tritium removal facilities in several countries have been granted permission to operate by their governments. The distinction must be made that military facilities are not licensed by energy development agencies, and commercial fission reactor tritium facilities such as those in Canada do not perform all of the tritium separation and removal tasks as fusion facilities, and they are licensed by fission reactor authorities. Any experiences or data that these other facilities can share with fusion can be very valuable, but fusion facilities will need to demonstrate their own safety. Making the fusion regulatory case for tritium usage is expected to progress in increments, proving each successive step. This "stair stepping" has been seen with JET (site limits $0.1 \mathrm{~g}$-T for the Preliminary Tritium Experiment and an administrative limit of $20 \mathrm{~g}$-T for the Deuterium-Tritium Experiment) ${ }^{1,2}$ and the Tokamak Fusion Test Reactor (TFTR, $5 \mathrm{~g}$-T site limit) experiences ${ }^{3}$ in magnetic fusion, and with the National Ignition Facility in inertial fusion. ${ }^{4}$ An ITERsize tritium facility $(<3 \mathrm{~kg}-\mathrm{T} \text { site limit })^{5}$ is another step forward for fusion and is expected to require a rigorous safety assessment. JET required both traditional and probabilistic safety analysis for tritium operations. Both JET and TFTR have demonstrated the value of probabilistic safety assessment for tritium systems, and the ITER design team has also used PSA techniques in the tritium systems safety assessment. ${ }^{6}$

The data that have been collected and analyzed from fusion tritium facilities are shared with task participants in the International Energy Agency's Implementing Agreement on the Environmental, Safety and Economic Aspects of Fusion Power (IEA/ESE-FP). ${ }^{7,8}$ The operating experience task in the IEA/ESE-FP gathers data from existing facilities for application to probabilistic safety assessment of the next successive step in fusion. Several tokamaks share data, including JET, the Frascati Tokamak Upgrade, Tore Supra, TFTR, and DIII-D. Other data values are found from records kept at other fusion facilities, such as the tritium labs. Literature sources and safety reports also supply data. Applicable data are also borrowed from other endeavors, such as the fission 
power, aerospace, and chemical process industries. Together, these data sets allow quantification of accidents in fusion facilities, which is part of the regulatory process in the US and some other countries.

This paper gives the results of a comparison of data values collected from TSTA, TPL, JET, and TLK. It is an extension of previous work that compared only US and Japanese data. ${ }^{9}$ The comparison process helps to validate the data and make selections of best estimate values. The data values presented here compared reasonably well.

\section{DATA VALUES}

Two objectives of the TSTA mission were to demonstrate the long-term safe handling of tritium and to demonstrate the long term reliability of components. ${ }^{10}$ In late 1999, the US Department of Energy (DOE) determined that the TSTA mission was complete and an orderly shutdown of the facility began in 2001. Facility stabilization was completed in 2003 and final cleanup is in progress. The component failure data records remaining at the site were electronically transmitted to the INEEL in August 2003 for inclusion in an update of the failure rate data values. Detailed examination of the transmitted data revealed that these electronic records were from the database inception in 1983 to the time that the KnowledgeMan database manager program originally used to store and sort the failure report data ${ }^{11,12}$ was converted to the R-base program for data storage. The conversion occurred in early 1990. Therefore, the transmitted records believed to be an update of past information were of limited use since they had already been included in past data analyses. It appears that the post-1990 data may have been lost. Despite the inability to perform a significant update on the TSTA component failure rate data values, comparing the collected data sets from TSTA $^{13-16}$ and other facilities remains a valuable exercise to validate the data.

Pinna ${ }^{17}$ has reported on an extensive data analysis performed on JET and TLK. Yamada et al. ${ }^{18,19}$ have reported two data sets on TPL. The second TPL data set has expanded some of the initially reported values and also examined some new components. The mean, or point estimate, failure rate values from the sets of failure reports or other recorded data at a given facility are given in Table I. Where relevant, both TPL data values are reported for a given component; the more recent values are used for comparison since longer periods of operating time generally result in more accurate failure rates. The second set of TPL values usually are smaller than the initial set. The table shows the expected result that some data values are very similar and some disagree. The IEA data task participants have concurred that values which agree to within a factor of 3 are considered a good comparison, those values that agree to within a factor of 10 are a fair comparison, and those values that vary more than a factor of 10 are a poor comparison. ${ }^{8}$ On a general level, facilities of similar age with similar types and numbers of components, and with similar duty factors and maintenance, usually produce comparable failure rate data. There can be many factors that affect individual results and make facility-to-facility comparisons poor, such as the influence of environmental conditions, the methods or style of component and system operation, and the maintenance approach of corrective versus predictive versus preventive. The TSTA data spans, on the order of 6 or more years of operation, are large enough for continuously operated components to produce mature failure rate values.

Some components listed in Table I do not have entries from each facility analyzed. Some facilities did not collect information on some types of components, and the data analyses did not focus on some types of components or systems. For example, from Table I it is obvious that TSTA and TPL researchers collected and analyzed glovebox data, while the JET and TLK analyses did not. Conversely, the JET analysis focused more on electronics while the TSTA, TPL, and TLK analyses did not. As more data are collected, broader sets of components can be analyzed and compared.

Failure rate comparisons are not easily made due to differences in components, differences in data reporting, and variations in the analysis. One example of reporting differences is the identification of failure modes. As seen in Table I, some components had 'all failure modes' failure rates, and other failure rate values had more specific modes. Often this discrepancy is due to the level of detail recorded in the component failure report and on a few occasions it is due to the chosen analysis technique of binning all of the data for an aggregate result. Overall, the number of 'good' comparisons was slightly higher than the number of fair and poor comparisons combined. Thus, the data compared reasonably well.

The values in Table I show that in general, some of the JET data produced the lowest values, in the 1E-06 and 1E-07 per hour range, while the TSTA and TPL data generally compare more closely in the 1E-05 per hour range. The JET Active Gas Handling System (AGHS) has not operated differently than the other facilities, and the components used at JET are believed to be similar to the other facilities. It is possible that the AGHS had larger populations of components, or perhaps the AGHS, being a fusion fuel processing system at a tokamak facility, had the impetus of experiment operations concerns that made maintenance more intensive than at the laboratory facilities. 
TABLE I. Tritium component failure rate comparison

\begin{tabular}{|c|c|c|c|c|c|}
\hline $\begin{array}{c}\text { Component and } \\
\text { failure mode }\end{array}$ & $\begin{array}{c}\text { TSTA } \\
\text { point estimate } \\
\text { and } \\
\text { (upper bound) }\end{array}$ & $\begin{array}{c}\text { TPL } \\
\text { point estimate } \\
\text { and } \\
\text { (upper bound) }\end{array}$ & $\begin{array}{c}\text { JET } \\
\text { point estimate } \\
\text { and } \\
\text { (upper bound) }\end{array}$ & $\begin{array}{c}\text { TLK } \\
\text { point estimate } \\
\text { and } \\
\text { (upper bound) }\end{array}$ & Comparison \\
\hline $\begin{array}{l}\text { Blower, } \\
\text { fail to function }\end{array}$ & -- & $\begin{array}{l}7.3 \mathrm{E}-05 / \mathrm{h} \\
(1.9 \mathrm{E}-04 / \mathrm{h})\end{array}$ & $\begin{array}{l}2.2 \mathrm{E}-05 / \mathrm{h} \\
(4.6 \mathrm{E}-05 / \mathrm{h})\end{array}$ & -- & fair \\
\hline $\begin{array}{l}\text { Gas } \\
\text { chromatograph, } \\
\text { fails to function }\end{array}$ & $\begin{array}{l}6.8 \mathrm{E}-02 / \mathrm{d} \\
(1.6 \mathrm{E}-01 / \mathrm{d})\end{array}$ & -- & -- & $\begin{array}{l}5.81 \mathrm{E}-06 / \mathrm{h} \\
(1.46 \mathrm{E}-05 / \mathrm{h}) \\
\text { [all modes] }\end{array}$ & not comparable \\
\hline $\begin{array}{l}\text { Motor operated } \\
\text { valve, fails to } \\
\text { open }\end{array}$ & $\begin{array}{l}5.0 \mathrm{E}-04 / \mathrm{d} \\
(8.5 \mathrm{E}-04 / \mathrm{d})\end{array}$ & -- & -- & $\begin{array}{l}2.06 \mathrm{E}-05 / \mathrm{h} \\
(6.49 \mathrm{E}-05 / \mathrm{h}) \\
\text { all modes }\end{array}$ & not comparable \\
\hline $\begin{array}{l}\text { Compressor, } \\
\text { fails to start }\end{array}$ & $\begin{array}{l}3.1 \mathrm{E}-05 / \mathrm{d} \\
(9.5 \mathrm{E}-05 / \mathrm{d})\end{array}$ & $\begin{array}{l}1.1 \mathrm{E}-04 / \mathrm{d} \\
(1.2 \mathrm{E}-04 / \mathrm{d}) \\
\\
5.2 \mathrm{E}-05 / \mathrm{d} \\
(5.67 \mathrm{E}-05 / \mathrm{d} \\
\text { assumed })\end{array}$ & -- & -- & $\begin{array}{l}\text { good, } \\
\text { later TPL data to } \\
\text { TSTA data compares } \\
\text { well }\end{array}$ \\
\hline $\begin{array}{l}\text { Compressor, } \\
\text { fails to run }\end{array}$ & $\begin{array}{l}6.3 \mathrm{E}-05 / \mathrm{h} \\
(1.6 \mathrm{E}-04 / \mathrm{h})\end{array}$ & $\begin{array}{l}8.1 \mathrm{E}-04 / \mathrm{h} \\
(2.1 \mathrm{E}-03 / \mathrm{h}) \\
\text { fail to function } \\
7.4 \mathrm{E}-04 / \mathrm{h} \\
(1.93 \mathrm{E}-03 / \mathrm{h} \\
\text { assumed }) \\
\text { failure }\end{array}$ & -- & $\begin{array}{l}3.62 \mathrm{E}-05 / \mathrm{h} \\
(1.72 \mathrm{E}-04 / \mathrm{h}) \\
\text { fails to run }\end{array}$ & $\begin{array}{l}\text { good, for TSTA data } \\
\text { to TLK data, } \\
\text { otherwise TPL data is } \\
\text { much higher }\end{array}$ \\
\hline $\begin{array}{l}\text { Manual valve, } \\
\text { fails to operate }\end{array}$ & $\begin{array}{l}1.8 \mathrm{E}-03 / \mathrm{d} \\
(3.2 \mathrm{E}-03 / \mathrm{d})\end{array}$ & $\begin{array}{l}9.8 \mathrm{E}-04 / \mathrm{d} \\
(5.4 \mathrm{E}-03 / \mathrm{d}) \\
\text { fails to function }\end{array}$ & -- & -- & good \\
\hline $\begin{array}{l}\text { Humidity } \\
\text { indicator, gives } \\
\text { incorrect value }\end{array}$ & $\begin{array}{l}1.7 \mathrm{E}-05 / \mathrm{h} \\
(3.9 \mathrm{E}-05 / \mathrm{h})\end{array}$ & $\begin{array}{l}2.1 \mathrm{E}-05 / \mathrm{h} \\
(3.9 \mathrm{E}-05 / \mathrm{h})\end{array}$ & $\begin{array}{l}9.8 \mathrm{E}-07 / \mathrm{h} \\
(1.4 \mathrm{E}-06 / \mathrm{h}) \\
\text { indicator, erratic }\end{array}$ & & $\begin{array}{l}\text { good, for TSTA to } \\
\text { TPL data; JET much } \\
\text { lower }\end{array}$ \\
\hline $\begin{array}{l}\text { Pressure } \\
\text { transducer, gives } \\
\text { incorrect value }\end{array}$ & $\begin{array}{l}5.3 \mathrm{E}-06 / \mathrm{h} \\
(1.4 \mathrm{E}-05 / \mathrm{h})\end{array}$ & -- & $\begin{array}{l}.3 \mathrm{E}-07 / \mathrm{h} \\
(1.3 \mathrm{E}-06 / \mathrm{h}) \\
\text { transducer, } \\
\text { erratic }\end{array}$ & & poor \\
\hline $\begin{array}{l}\text { Recombiner, } \\
\text { fails to function }\end{array}$ & $\begin{array}{l}4.2 \mathrm{E}-05 / \mathrm{h} \\
(1.3 \mathrm{E}-04 / \mathrm{h})\end{array}$ & -- & -- & -- & -- \\
\hline $\begin{array}{l}\text { Room air } \\
\text { monitor, } \\
\text { reads high }\end{array}$ & $\begin{array}{l}2.2 \mathrm{E}-06 / \mathrm{h} \\
(1.0 \mathrm{E}-05 / \mathrm{h})\end{array}$ & $\begin{array}{l}1.1 \mathrm{E}-05 / \mathrm{h} \\
(2.2 \mathrm{E}-05 / \mathrm{h}) \\
\text { fails to function }\end{array}$ & $\begin{array}{l}8.8 \mathrm{E}-07 / \mathrm{h} \\
(4.2 \mathrm{E}-06 / \mathrm{h}) \\
\text { ion chamber, } \\
\text { erratic or no } \\
\text { output }\end{array}$ & -- & $\begin{array}{l}\text { TSTA data to JET } \\
\text { data good, TPL data } \\
\text { is much higher }\end{array}$ \\
\hline $\begin{array}{l}\text { Room air } \\
\text { monitor, } \\
\text { reads low }\end{array}$ & $\begin{array}{l}2.2 \mathrm{E}-06 / \mathrm{h} \\
(1.0 \mathrm{E}-05 / \mathrm{h})\end{array}$ & $\begin{array}{l}1.1 \mathrm{E}-05 / \mathrm{h} \\
(2.2 \mathrm{E}-05 / \mathrm{h}) \\
\text { fails to function }\end{array}$ & $\begin{array}{l}8.8 \mathrm{E}-07 / \mathrm{h} \\
(4.2 \mathrm{E}-06 / \mathrm{h}) \\
\text { ion chamber, } \\
\text { erratic or no } \\
\text { output }\end{array}$ & -- & $\begin{array}{l}\text { TSTA data to JET } \\
\text { data good, TPL data } \\
\text { is much higher }\end{array}$ \\
\hline
\end{tabular}


TABLE I. Continued.

\begin{tabular}{|c|c|c|c|c|c|}
\hline $\begin{array}{c}\text { Component and } \\
\text { failure mode }\end{array}$ & $\begin{array}{c}\text { TSTA } \\
\text { point estimate } \\
\text { and } \\
\text { (upper bound) }\end{array}$ & $\begin{array}{c}\text { TPL } \\
\text { point estimate } \\
\text { and } \\
\text { (upper bound) }\end{array}$ & $\begin{array}{c}\text { JET } \\
\text { point estimate } \\
\text { and } \\
\text { (upper bound) }\end{array}$ & $\begin{array}{c}\text { TLK } \\
\text { point estimate } \\
\text { and } \\
\text { (upper bound) }\end{array}$ & Comparison \\
\hline $\begin{array}{l}\text { Glovebox } \\
\text { pressure } \\
\text { controller, } \\
\text { overpressure }\end{array}$ & $\begin{array}{l}\text { 3.0E-01/year } \\
(4.0 \mathrm{E}-01 / \text { year })\end{array}$ & $\begin{array}{l}2.9 \mathrm{E}-02 / \text { year } \\
(1.4 \mathrm{E}-01 / \mathrm{h}) \\
\text { fails to function } \\
6.9 \mathrm{E}-02 / \text { year } \\
(3.3 \mathrm{E}-01 / \text { year } \\
\text { assumed), } \\
\text { negative pressure } \\
\text { control failure }\end{array}$ & -- & -- & poor \\
\hline $\begin{array}{l}\text { Glovebox } \\
\text { pressure } \\
\text { controller, } \\
\text { underpressure }\end{array}$ & $\begin{array}{l}\text { 2.0E-01/year } \\
(3.0 \mathrm{E}-01 / \text { year })\end{array}$ & $\begin{array}{l}2.9 \mathrm{E}-02 / \text { year } \\
(1.4 \mathrm{E}-01 / \text { year }) \\
\text { fails to function } \\
6.9 \mathrm{E}-02 / \text { year } \\
(3.3 \mathrm{E}-01 / \text { year } \\
\text { assumed), } \\
\text { negative pressure } \\
\text { control failure }\end{array}$ & -- & -- & poor \\
\hline $\begin{array}{l}\text { Glovebox } \\
\text { pressure } \\
\text { controller, } \\
\text { continuously } \\
\text { purges }\end{array}$ & $\begin{array}{l}\text { 4.0E-02/year } \\
(1.0 \mathrm{E}-01 / \text { year })\end{array}$ & $\begin{array}{l}6.9 \mathrm{E}-02 / \text { year } \\
\text { negative pressure } \\
\text { control failure }\end{array}$ & -- & -- & good \\
\hline $\begin{array}{l}\text { Glovebox, air } \\
\text { inleakage }\end{array}$ & $\begin{array}{l}\text { 1.0E-01/year } \\
\text { (5.0E-01/year) }\end{array}$ & $\begin{array}{l}1.14 \mathrm{E}-01 / \text { year } \\
(2.6 \mathrm{E}-01 / \text { year })\end{array}$ & -- & -- & good \\
\hline $\begin{array}{l}\text { Glovebox, small } \\
\text { scale tritium } \\
\text { release to room }\end{array}$ & $\begin{array}{l}\text { 4.0E-02/year } \\
(1.0 \mathrm{E}-01 / \text { year })\end{array}$ & & -- & -- & -- \\
\hline $\begin{array}{l}\text { Oxygen monitor, } \\
\text { all failure modes }\end{array}$ & $\begin{array}{l}3.4 \mathrm{E}-07 / \mathrm{h} \\
(2.3 \mathrm{E}-06 / \mathrm{h})\end{array}$ & $\begin{array}{l}7.2 \mathrm{E}-06 / \mathrm{h} \\
(1.3 \mathrm{E}-05 / \mathrm{h}) \\
\text { fails to function } \\
3.0 \mathrm{E}-06 / \mathrm{h} \\
\text { oxygen sensor } \\
\text { failure }\end{array}$ & -- & -- & fair \\
\hline $\begin{array}{l}\text { Small } \\
\text { compressor, fails } \\
\text { to run }\end{array}$ & $\begin{array}{l}6.3 \mathrm{E}-05 / \mathrm{h} \\
(1.6 \mathrm{E}-04 / \mathrm{h})\end{array}$ & $\begin{array}{l}8.1 \mathrm{E}-04 / \mathrm{h} \\
(2.1 \mathrm{E}-03 / \mathrm{h})\end{array}$ & -- & -- & poor \\
\hline $\begin{array}{l}\text { Small } \\
\text { compressor, fails } \\
\text { to start }\end{array}$ & $\begin{array}{l}3.1 \mathrm{E}-05 / \mathrm{d} \\
(9.5 \mathrm{E}-05 / \mathrm{d})\end{array}$ & $\begin{array}{l}1.1 \mathrm{E}-04 / \mathrm{d} \\
(1.2 \mathrm{E}-04 / \mathrm{d})\end{array}$ & -- & -- & poor \\
\hline $\begin{array}{l}\text { U getter bed with } \\
\text { heaters }\end{array}$ & -- & -- & -- & $\begin{array}{l}8.04 \mathrm{E}-04 / \mathrm{h} \\
(2.02 \mathrm{E}-03 / \mathrm{h}) \\
\text { all failure modes }\end{array}$ & -- \\
\hline $\begin{array}{l}\text { ZrCo getter bed } \\
\text { with heater }\end{array}$ & -- & -- & -- & $\begin{array}{l}1.53 \mathrm{E}-02 / \mathrm{h} \\
(3.84 \mathrm{E}-02 / \mathrm{h}) \\
\text { all failure modes }\end{array}$ & -- \\
\hline $\begin{array}{l}\text { Molecular sieve } \\
\text { bed }\end{array}$ & -- & -- & -- & $\begin{array}{l}3.56 \mathrm{E}-07 / \mathrm{h} \\
(8.94 \mathrm{E}-07 / \mathrm{h}) \\
\text { all failure modes }\end{array}$ & -- \\
\hline
\end{tabular}


As an initial approach to obtaining generic failure rates, the values in Table I were combined using a geometric mean to produce average failure rates. Then the values were rounded up to the nearest half-order of magnitude. The upper bounds are 90 or $95 \%$ confidence interval values. These failure rates and their error bounds are considered to be the generic average based on the operating experience of the facilities. The results are given in Table II. These generic failure rate values can be used for preliminary safety assessment when components are not well defined or do not have input data from the manufacturers. Pinna ${ }^{17}$ also reported some generic values based on the JET AGHS data results.

\section{CONCLUSIONS}

The collection of system and component operating experience at multiple facilities has allowed analysts to calculate component failure rates for tritium-bearing components. These are truly fusion-specific data sets, and they allow direct application of probabilistic safety assessment to fusion tritium systems. These data are more accurate and applicable to fusion than analyst judgment, generic gas system data, or tritium system data from military or other applications. Collecting the operating experience data is an important part of proving that tritium can be handled safely for fusion experiments and having these data advances the state-of-the-art for probabilistic safety assessment in fusion applications. The data can support facility-specific uses, such as a safety assessment update needed when petitioning to increase the allowable tritium inventory. The data values in Table I compared reasonably well, although in a few cases there were large variations in the data. For components that have wide variation in values, using generic results may offer the best quantification unless facility-specific data are to be used. The generic failure rates given in Table II can also be used for preliminary safety assessments when only the types of system components are known. All of these data can be shared with the IEA/ESE-FP task on component failure rate data collection for safety support.

\section{ACKNOWLEDGMENTS}

This work was prepared for the US Department of Energy (DOE), Office of Fusion Energy Sciences, under the DOE Idaho Operations Office contract number DE-AC0799ID13727.
TABLE II. Generic tritium component failure rates

\begin{tabular}{|l|c|c|}
\hline \multicolumn{1}{|c|}{$\begin{array}{c}\text { Component and } \\
\text { failure mode }\end{array}$} & $\begin{array}{c}\text { Generic } \\
\text { failure rate }\end{array}$ & $\begin{array}{c}\text { Upper bound } \\
\text { failure rate }\end{array}$ \\
\hline $\begin{array}{l}\text { Blower, } \\
\text { fails to function }\end{array}$ & $3 \mathrm{E}-05 / \mathrm{h}$ & $1 \mathrm{E}-04 / \mathrm{h}$ \\
\hline $\begin{array}{l}\text { Compressor, } \\
\text { fails to start }\end{array}$ & $3 \mathrm{E}-05 / \mathrm{d}$ & $1 \mathrm{E}-04 / \mathrm{d}$ \\
\hline $\begin{array}{l}\text { Compressor, } \\
\text { fails to run }\end{array}$ & $1 \mathrm{E}-04 / \mathrm{h}$ & $3 \mathrm{E}-04 / \mathrm{h}$ \\
\hline $\begin{array}{l}\text { Manual valve, } \\
\text { fails to operate }\end{array}$ & $1 \mathrm{E}-03 / \mathrm{d}$ & $3 \mathrm{E}-03 / \mathrm{d}$ \\
\hline $\begin{array}{l}\text { Humidity indicator, } \\
\text { incorrect output }\end{array}$ & $1 \mathrm{E}-05 / \mathrm{h}$ & $3 \mathrm{E}-05 / \mathrm{h}$ \\
\hline $\begin{array}{l}\text { Pressure } \\
\text { transducer, } \\
\text { incorrect output }\end{array}$ & $1 \mathrm{E}-06 / \mathrm{h}$ & $1 \mathrm{E}-06$ \\
\hline $\begin{array}{l}\text { Room air monitor, } \\
\text { reads high }\end{array}$ & $3 \mathrm{E}-06 / \mathrm{h}$ \\
\hline $\begin{array}{l}\text { Room air monitor, } \\
\text { reads low }\end{array}$ & $3 \mathrm{E}-06 / \mathrm{h}$ & $1 \mathrm{E}-05 / \mathrm{h}$ \\
\hline $\begin{array}{l}\text { Glovebox pressure } \\
\text { controller, } \\
\text { overpressure }\end{array}$ & $1 \mathrm{E}-01 /$ year & $3 \mathrm{E}-01 /$ year \\
\hline $\begin{array}{l}\text { Glovebox pressure } \\
\text { controller, } \\
\text { underpressure }\end{array}$ & $1 \mathrm{E}-01 /$ year & $3 \mathrm{E}-01 /$ year \\
\hline $\begin{array}{l}\text { Glovebox pressure } \\
\text { controller, } \\
\text { continuous purge }\end{array}$ & $1 \mathrm{E}-01 /$ year & $3 \mathrm{E}-01 /$ year \\
\hline $\begin{array}{l}\text { Glovebox, } \\
\text { air inleakage }\end{array}$ & $1 \mathrm{E}-01 /$ year \\
\hline $\begin{array}{l}\text { Oxygen monitor, } \\
\text { all failure modes }\end{array}$ & $1 \mathrm{E}-06 / \mathrm{h}$ & $3 \mathrm{E}-01 /$ year \\
\hline $\begin{array}{l}\text { Small compressor, } \\
\text { fails to run }\end{array}$ & $3 \mathrm{E}-04 / \mathrm{h}$ & $1 \mathrm{E}-03 / \mathrm{h}$ \\
\hline $\begin{array}{l}\text { Small compressor, } \\
\text { fails to start }\end{array}$ & $3 \mathrm{E}-05 / \mathrm{d}$ & $1 \mathrm{E}-04 / \mathrm{d}$ \\
\hline
\end{tabular}

note: $/ \mathrm{h}$ is per operating hour, $/ \mathrm{d}$ is per demand to function

\section{REFERENCES}

1. A. C. BELL, M. WYKES, and B. J. GREEN, "Safety aspects and approvals of the first JET tritium experiment," Fusion Engineering and Design, 19, 169 (1992).

2. A. C. BELL, P. BALLANTYNE, C. GORDONT, M. A. WRIGHT, "The safety case for JET D-T operation," Fusion Engineering and Design, 47, 115 (1999).

3. The Tokamak Fusion Test Reactor D-T Modifications and Operations, DOE/EA-0566, US Department of Energy, Washington, DC (1992). 
4. National Ignition Facility Preliminary Safety Analysis Report, UCRL-ID-123759, Lawrence Livermore National Laboratory (1996).

5. ITER Technical Basis, ITER EDA Documentation Series No. 24, IAEA Vienna, Chapter V (2002).

6. T. PINNA, C. RIZZELLO, "Safety assessment for ITER-FEAT tritium systems," Fusion Engineering and Design, 63-64, 181 (2002).

7. T. PINNA, L. C. CADWALLADER, "Component Failure Rate Data Base for Fusion Applications," Fusion Engineering and Design, 51-52, 579 (2000).

8. L. C. CADWALLADER and T. PINNA, "Progress Toward a Component Failure Rate Data Bank for Magnetic Fusion Safety," Proceedings of the International Topical Meeting on Probabilistic Safety Assessment, PSA '99, August 22-26, 1999, Washington, DC, American Nuclear Society, 11 (1999).

9. L. C. CADWALLADER, "Comparisons of facilityspecific and generic component failure rates for tritium-bearing components used in fusion research," Fusion Engineering and Design, 54, 353 (2001).

10. J. L. ANDERSON, "Tritium Systems Test Assembly: Objectives and Design," LA-UR-79-2971, Los Alamos National Laboratory (1980).

11. K. GRUETZMACHER and R. C. WILHELM, "Data Base for Failure/Maintenance at the Tritium Systems Test Assembly," Fusion Technology, 10, 1596 (1986).

12. M. A. CASEY, K. M. GRUETZMACHER, J. R. BARTLIT, and L. C. CADWALLADER, "The Data Collection System for Failure/Maintenance at the Tritium Systems Test Assembly," Fusion Technology, 14, 962 (1988).
13. L. C. CADWALlADER and M. A. STOLPEGAVET, Tritium Waste Treatment System Component Failure Data Analysis from June 18, 1984 to December 31, 1989, EGG-FSP-8973, revision 1, Idaho National Engineering Laboratory (1990)

14. L. C. CADWALLADER, M. A. STOLPE-GAVET, and L. QUINTANA, Tritium Room Air Monitor Component Failure Rate Data Analysis from January 1, 1984 to December 31, 1990, EGG-FSP-9450, Idaho National Engineering Laboratory (1991).

15. L. C. CADWALLADER and D. P. SANCHEZ, Secondary Containment System Component Failure Data Analysis from 1984 to 1992, EGG-FSP-10323, Idaho National Engineering Laboratory (1992).

16. L. C. CADWALLADER and G. L. TAYLOR, Experimental Tritium Cleanup System Availability Analysis from 1984 to 1992, EGG-FSP-10603, Idaho National Engineering Laboratory (1993).

17. T. PINNA, G. CAMBI, A. LO BUE, and C. RIZZELLO, Collection and Analysis of Data Related to Fusion Machines (JET and TLK) Operation Experience on Component Failures, FUS-TN-SASE-R-058, ENEA, Frascati, Italy (2003).

18. M. YAMADA et al., "Operation Experience on Safety System of Tritium Process Laboratory in Japan Atomic Energy Research Institute," Fusion Technology, 28, 1376 (1995).

19. M. YAMADA et al., "Operation Results on Safety Systems of Tritium Process Laboratory in Japan Atomic Energy Research Institute," Fusion Science and Technology, 41, 593 (2002). 